\title{
ANALISIS LALU LINTAS PENERAPAN SISTEM SATU ARAH DI KAWASAN DUKUH ATAS, JAKARTA
}

\author{
Budi Hartanto Susilo ${ }^{1}$, Ivan Imanuel ${ }^{2}$ \\ ${ }^{1}$ Guru Besar, Program Studi Teknik Sipil, Fakultas Teknik, Universitas Kristen Maranatha \\ ${ }^{2}$ Alumni, Program Studi Teknik Sipil, Fakultas Teknik, Universitas Kristen Maranatha \\ Email: budiharsus@yahoo.com,ivan.imanuel@yahoo.com
}

\begin{abstract}
ABSTRAK
Dukuh Atas merupakan tempat bertemunya lima moda transportasi Jakarta di pusat kota. Dengan masalah kemacetan yang parah pada jam sibuk, Dinas Perhubungan DKI Jakarta berencana menerapkan manajemen dan rekayasa lalu lintas Sistem Satu Arah pada kawasan tersebut. Studi ini membahas dampak lalu lintas penerapan SSA di Dukuh Atas dengan analisis mikrosimulasi menggunakan Vissim. Hasil studi menunjukkan dengan adanya SSA, rata-rata kecepatan pada ruas jalan meningkat dari $15,5 \mathrm{~km} / \mathrm{jam}$ menjadi $17,7 \mathrm{~km} / \mathrm{jam}$ dan tundaan pada simpang berkurang dari $60,3 \mathrm{detik} /$ kendaraan menjadi 43,7 detik/kendaraan.
\end{abstract}

Kata Kunci: lalu lintas, manajemen dan rekayasa, sistem satu arah, Dukuh Atas, Vissim.

\section{ABSTRACT}

Dukuh Atas is an area where five modes of transportation in Jakarta meet in the city center. Due to heavy traffic congestion problems on rush hours, the Department of Transportation of Jakarta plans to implement traffic management called hone way system at the area. This study tells about the impact of the one-way system on traffic at Dukuh Atas with microsimulation analysis using Vissim. The result shows an increment of average speed on road sections from $15.5 \mathrm{~km} / \mathrm{hour}$ to $17.7 \mathrm{~km} / \mathrm{hour}$ and reduced average delays on road intersections from 60.3 seconds/vehicle to 43.7 seconds/vehicle.

Keywords: traffic engineering, traffic management, one-way system, Dukuh Atas, Vissim.

\section{PENDAHULUAN}

Kawasan Dukuh Atas merupakan tempat bertemunya MRT, LRT, KRL, kereta bandara dan busway seperti terlihat pada Gambar 1. Sebagai kawasan penting di pusat kota, Dukuh Atas mengalami kendala kemacetan lalu lintas yang parah terutama pada jam sibuk. Kemacetan memang merupakan masalah umum di Jakarta sejak beberapa tahun terakhir. Hal ini disebabkan oleh transportasi yang berorientasi pada jalan dan kendaraan pribadi (Putranto, 2010). Kerugian akibat kemacetan di sepanjang Jl. Jend. Sudirman, Jakarta diperkirakan mencapai Rp 19 trilyun/tahun (Syaukat et al., 2015). Dalam rangka mengurai kemacetan tersebut Dinas Perhubungan Provinsi DKI Jakarta berencana menerapkan manajemen dan rekayasa lalu lintas sistem satu arah di kawasan Dukuh Atas.

Sistem Satu Arah (SSA) merupakan salah satu manajemen lalu lintas dengan cara membuat jalan satu arah pada beberapa ruas jalan yang saling berhubung hingga 
mengelilingi suatu wilayah. Dengan adanya SSA, diharapkan konflik kendaraan di simpang-simpang berkurang sehingga pergerakan arus lalu lintas menjadi lebih lancar. SSA sendiri sudah banyak diterapkan pada kota-kota besar di Indonesia, beberapa contohnya di Tanah Abang, Sawah Besar, Kebayoran Baru, dan Jatinegara di Jakarta, Pasirkaliki, Babakan Ciamis, dan Balonggede di Bandung, Petisah Tengah di Medan, Krembangan dan Genteng di Surabaya, Karampuang di Makassar dan tempat-tempat lainnya.

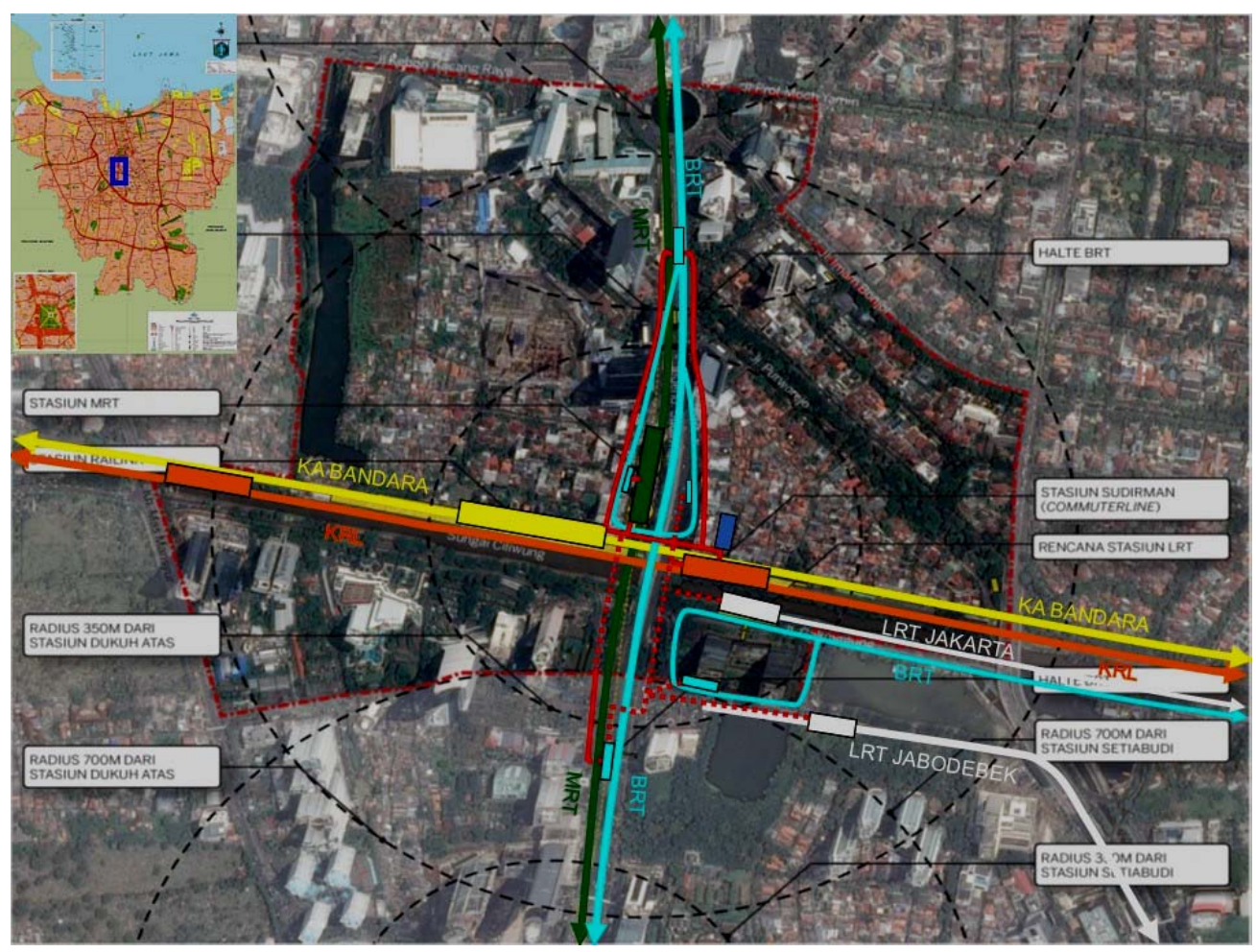

Sumber: PT MRT Jakarta (2018)

Gambar 1. Dukuh Atas, tempat bertemunya 5 moda transportasi Jakarta

Apakah SSA mampu meningkatkan kecepatan lalu lintas di kawasan Dukuh Atas? Studi ini bertujuan untuk memperkirakan dampak lalu lintas penerapan SSA pada kawasan Dukuh Atas menggunakan mikrosimulasi dengan perangkat lunak Vissim 11. Studi ini merupakan penelitian eksperimen terhadap pergerakan lalu lintas menggunakan model mikrosimulasi terhadap kondisi eksisting (do nothing) dan kondisi rencana (do something). Beberapa studi serupa berkaitan analisis lalu lintas dengan mikrosimulasi Vissim telah dipublikasikan. Irawan dan Putri (2015) menyusun kalibrasi model Vissim pada simpang bersinyal dengan studi kasus Simpang Tugu, Yogyakarta. Negoro et al. 
(2018) menganalisis pengaruh lima skenario manajemen kecepatan terhadap panjang antrean pada gerbang tol Palimanan. Menggunakan Vissim juga, Wikayanti et al. (2018) mengusulkan solusi peningkatan kinerja simpang dengan cara pengaturan siklus dan pelebaran lengan.

\section{METODOLOGI PENELITIAN}

Studi analisis dampak lalu lintas penerapan kawasan Dukuh Atas ini secara garis besar dimulai dari pengumpulan data, pemodelan lalu lintas, kalibrasi dan validasi, analisis perbandingan, dan penyusunan kesimpulan dan rekomendasi. Tahapan kegiatan studi ini dijelaskan dengan diagram alir pada Gambar 2.

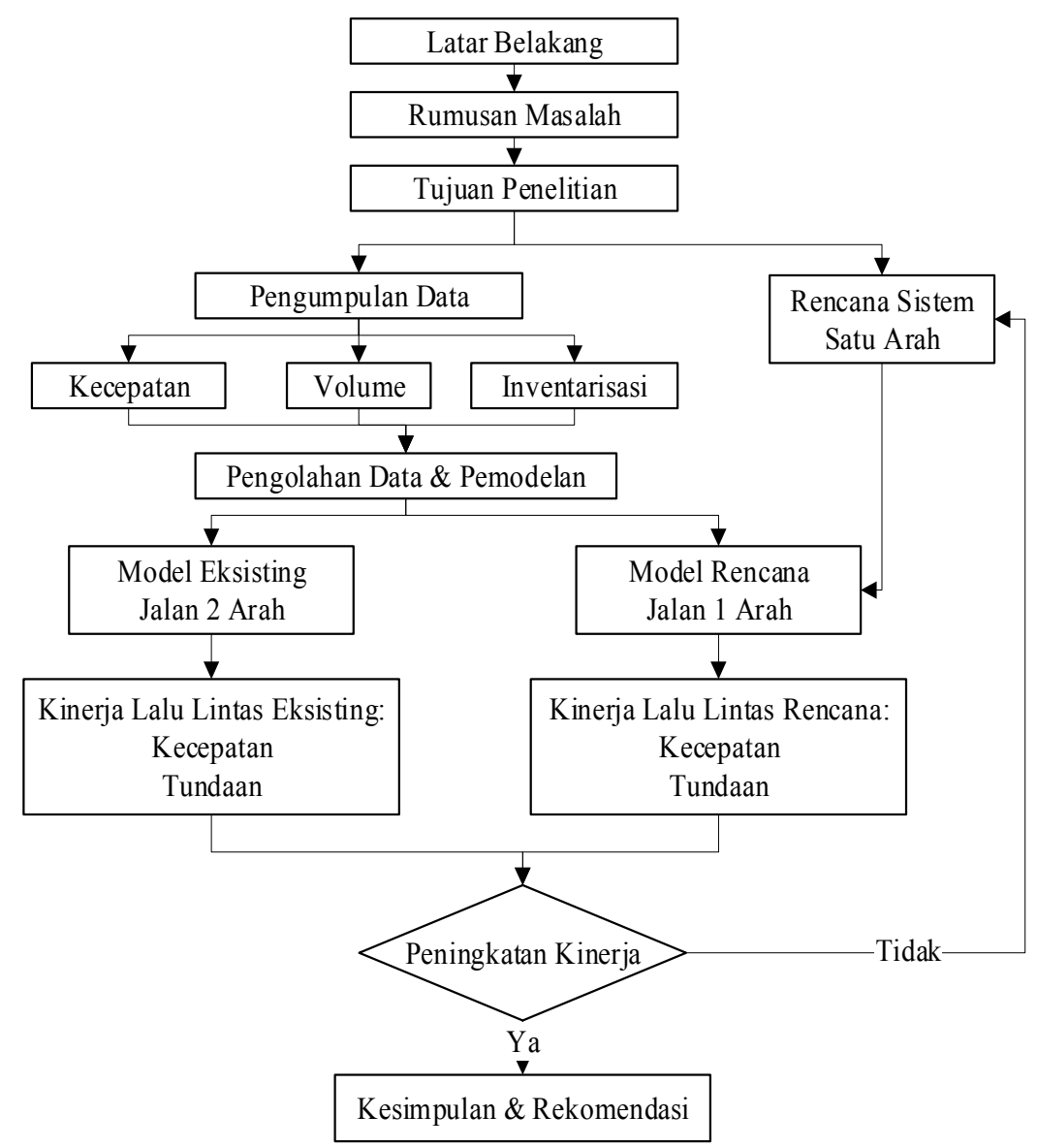

Gambar 2. Diagram alir tahapan studi

Pemodelan lalu lintas dalam studi ini menggunakan pendekatan pembebanan lalu lintas statis. Artinya pola pergerakan asal, tujuan, dan rute perjalanan lalu lintas dalam kawasan yang ditinjau telah ditentukan sebelumnya dan tidak berubah selama simulasi. 
Kalibrasi perilaku lalu lintas dan validasi model lalu lintas berdasarkan parameter volume dan kecepatan perjalanan. Validasi model menggunakan metode $\mathrm{R}^{2}$. Pembatasan wilayah studi juga perlu dilakukan agar analisis dapat lebih terfokus pada dampak lalu lintas penerapan SSA. Jaringan jalan yang ditinjau antara lain Jl. Jenderal Sudirman, Jl. R.M Margono Djojohadikusumo, Jl. Galunggung, Jl. Setia Budi Tengah, Ramp Barat, Ramp Timur, sisi barat Landmark dan sisi timur Landmark.

Model rencana terdiri atas pengaturan lalu lintas seperti terlihat pada Gambar 3, dengan rincian:

1. sisi selatan (Jl. Setia Budi Tengah) menjadi satu arah dari timur ke barat, atau dari arah Manggarai menuju Dukuh atas;

2. sisi barat Landmark menjadi satu arah dari selatan ke utara, atau menuju Jalan Galunggung maupun Jl. R.M Margono Djojohadikusumo;

3. sisi utara (Jl. Galunggung) satu arah dari barat ke timur, atau dari arah Dukuh Atas menuju Manggarai;

4. sisi timur Landmark menjadi satu arah dari utara ke selatan.

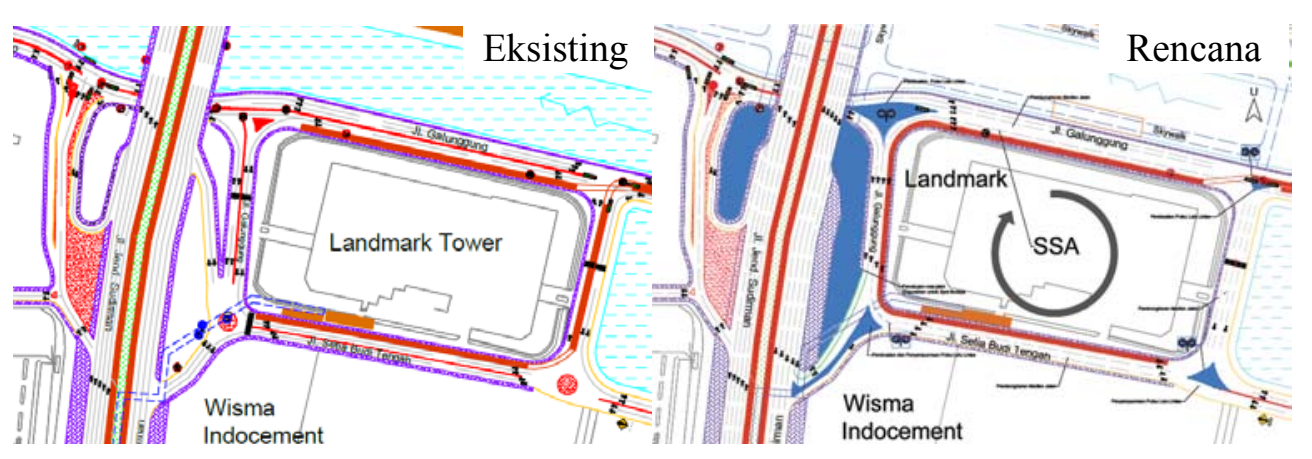

Gambar 3. Kondisi Eksisting dan Rencana SSA di Dukuh Atas

\section{PENGUMPULAN DATA}

Untuk membuat model lalu lintas, survei inventarisasi jalan terlebih dahulu dilakukan. Survei inventarisasi jalan mengikuti Tata Cara No. 017/T/BNKT/1990. Survei ini meliputi pendataan ruas jalan dan simpang, tipe jalan, lebar jalan, pengaturan lalu lintas (rambu, marka, median, separator, dan lain-lain). Tabel 1 menunjukkan hasil inventarisasi jalan pada 14 ruas jalan di kawasan Dukuh Atas, Jakarta.

Pengumpulan data volume lalu lintas sesuai dengan Pd. T-19-2004-B tentang survei pencacahan lalu lintas dengan cara manual, pada hari kerja jam 
sibuk sore hari saat lalu lintas mengalami puncak kepadatan, dengan hasil sebagaimana terlihat pada Tabel 2 Pada saat yang bersamaan juga dilakukan pengukuran waktu perjalanan lalu lintas untuk menyatakan kinerja lalu lintas secara aktual. Survei waktu perjalanan mengikuti Panduan No. 001/T/BNKT/1990 menggunakan metode kendaraan contoh (floating car method).

Tabel 1. Inventarisasi Ruas Jalan di Kawasan Dukuh Atas

\begin{tabular}{|c|c|c|c|c|c|c|}
\hline \multirow[b]{2}{*}{ No. } & \multirow[b]{2}{*}{ Nama Jalan } & \multirow[b]{2}{*}{$\begin{array}{c}\text { Tipe } \\
\text { Jalan }\end{array}$} & \multicolumn{3}{|c|}{ Lebar } & \multirow[b]{2}{*}{$\begin{array}{c}\text { Hambatan } \\
\text { Samping }\end{array}$} \\
\hline & & & $\begin{array}{c}\text { Lajur } \\
\text { (m) }\end{array}$ & $\begin{array}{c}\text { Bahu } \\
\text { (m) }\end{array}$ & $\begin{array}{c}\text { Trotoar } \\
\text { (m) }\end{array}$ & \\
\hline 1 & Jl. Jenderal Sudirman 1 & \multirow{3}{*}{$10 / 2 \mathrm{D}$} & & & & \\
\hline a. & Arah Bundaran HI (Utara) & & 3,46 & 0,5 & 9,5 & Tinggi \\
\hline b. & Arah Senayan (Selatan) & & 3,46 & 0,5 & 9,5 & Tinggi \\
\hline 2 & \multicolumn{6}{|c|}{ Jl. Jenderal Sudirman 2 (jembatan) } \\
\hline a. & Arah Bundaran HI (Utara) & \multirow{2}{*}{$10 / 2 \mathrm{D}$} & 3,1 & 0,5 & $5-9,5$ & Tinggi \\
\hline b. & Arah Senayan (Selatan) & & 3,4 & 0,5 & $5-9,5$ & Tinggi \\
\hline 3 & \multicolumn{6}{|l|}{ Jl. RM Margono Djojohadikusumo } \\
\hline a. & Arah Tanah Abang (Barat) & \multirow{2}{*}{$4 / 2 \mathrm{D}$} & 3,3 & 0,5 & $1,5-3$ & Rendah \\
\hline b. & Arah Manggarai (Timur) & & 3 & 0,5 & $1,5-3$ & Sedang \\
\hline 4 & Jl. Galunggung 1 (underpass) & & & & & \\
\hline a. & Arah Tanah Abang (Barat) & \multirow{2}{*}{$4 / 2 \mathrm{D}$} & 3,5 & 0,5 & $1,5-3$ & Rendah \\
\hline b. & Arah Manggarai (Timur) & & 3,5 & 0,5 & $1,5-3$ & Sedang \\
\hline 5 & \multicolumn{6}{|c|}{ Jl. Galunggung 2 (utara Landmark) } \\
\hline a. & Arah Tanah Abang (Barat) & \multirow{2}{*}{$7 / 2 \mathrm{D}$} & 3 & 0,5 & 0,5 & Rendah \\
\hline b. & Arah Manggarai (Timur) & & 3 & 0,5 & 1,5 & Sedang \\
\hline 6 & \multicolumn{6}{|c|}{ Jl. Galunggung 3 (utara waduk Setia Budi) } \\
\hline a. & Arah Tanah Abang (Barat) & \multirow{2}{*}{$6 / 2 \mathrm{D}$} & 3 & 0,5 & 1,5 & Sedang \\
\hline b. & Arah Manggarai (Timur) & & 3 & 0,5 & 0,5 & Rendah \\
\hline 7 & \multicolumn{6}{|c|}{ Jl. Setia Budi Tengah 1 (selatan Landmark) } \\
\hline a. & Arah Sudirman (Barat) & \multirow[b]{2}{*}{$5 / 2 \mathrm{D}$} & 2,8 & - & 1 & Tinggi \\
\hline b. & Arah Manggarai (Timur) & & 2,6 & - & 1 & Sedang \\
\hline 8 & \multicolumn{6}{|c|}{ Jl. Setia Budi Tengah 2 (selatan waduk Setia Budi) } \\
\hline a. & Arah Sudirman (Barat) & \multirow{2}{*}{$4 / 2 \mathrm{D}$} & 3,5 & & 2 & Rendah \\
\hline b. & Arah Manggarai (Timur) & & 3,5 & & 2 & Rendah \\
\hline 9 & Jl. Sisi Barat Landmark & \multirow{3}{*}{$4 / 2 \mathrm{D}$} & & & & \\
\hline a. & Arah underpass (Utara) & & 3,25 & - & 1 & Sedang \\
\hline b. & Arah Sudirman (Selatan) & & 3,5 & 0,5 & 1,5 & Tinggi \\
\hline 10 & J1. Sisi Timur Landmark & \multirow{3}{*}{$4 / 2 \mathrm{D}$} & & & & \\
\hline a. & Arah Galunggung (Utara) & & 3,5 & - & 1,5 & Rendah \\
\hline b. & Arah Setia Budi (Selatan) & & 3,5 & 1 & 2 & Sedang \\
\hline 11 & Ramp Sudirman Barat & & & & & \\
\hline a. & Arah Margono (keluar) & \multirow{3}{*}{$2 / 1$} & \multirow{3}{*}{$\begin{array}{l}3,5 \\
3,5\end{array}$} & - & $1,5-3$ & Sedang \\
\hline b. & Arah Sudirman (masuk) & & & \multirow[t]{2}{*}{-} & \multirow[t]{2}{*}{$1,5-3$} & Sedang \\
\hline 12 & Ramp Sudirman Timur & & & & & \\
\hline a. & Arah Setia Budi (keluar) & $2 / 1$ & 4,5 & - & 0,5 & Sedang \\
\hline b. & Arah Sudirman (masuk) & $2 / 1$ & 3,75 & - & 1,5 & Sedang \\
\hline 13 & Jl. Karet Pasar Baru Timur III & & & & & \\
\hline a. & Arah Mas Mansyur (ke Barat) & & 4,5 & - & 0,5 & Sedang \\
\hline b. & Arah Sudirman (ke Timur) & $2 / 2 \mathrm{UD}$ & 4,5 & - & 0,5 & Tinggi \\
\hline
\end{tabular}


Pengendalian lalu lintas di simpang dengan APILL merupakan salah satu input pada model sehingga memerlukan pengukuran waktu sinyal untuk setiap pendekat. Terdapat 2 simpang ber-APILL di Dukuh Atas, yaitu simpang Ramp Sudirman Barat-Margono Djojohadikusumo (Dukuh Bawah) dan simpang Galunggung-Sisi Timur Landmark (Galunggung).

Tabel 2. Volume Lalu Lintas di Kawasan Dukuh Atas

\begin{tabular}{lcccccc}
\hline \multicolumn{1}{c}{ Ruas Jalan } & Arah & $\begin{array}{c}\text { Volume } \\
\text { (kend/jam) }\end{array}$ & SM & KR & KB & KTB \\
\hline Sudirman & U-S & 6767 & 4719 & 1920 & 121 & 7 \\
Sudirman & S-U & 6330 & 3732 & 2479 & 116 & 3 \\
Thamrin & U-S & 8249 & 4662 & 3534 & 45 & 8 \\
Thamrin & S-U & 4659 & 3034 & 1502 & 118 & 5 \\
Galunggung & B-T & 4063 & 3394 & 616 & 42 & 11 \\
Galunggung & T-B & 6396 & 5466 & 862 & 56 & 12 \\
Setia Budi & U-S & 2890 & 1788 & 1094 & 8 & 0 \\
Setia Budi & S-U & 2167 & 1455 & 709 & 3 & 0 \\
Margono & B-T & 4756 & 3726 & 1003 & 19 & 8 \\
Margono & T-B & 4517 & 3179 & 1309 & 24 & 5 \\
Karet Pasar Baru III & B-T & 1331 & 859 & 465 & 7 & 0 \\
Karet Pasar Baru III & T-B & 509 & 326 & 181 & 2 & 0 \\
\hline SM $=$ Sepeda Motor, KR $=$ Kendaraan Ringan, KB = Kendaraan Berat, KTB = Kendaraan Tak Bermotor
\end{tabular}

\section{PEMODELAN LALU LINTAS DAN ANALISIS}

Hasil output model eksisting dari Vissim divalidasi dengan data survei lapangan, seperti terlihat pada Gambar 4. Nilai $R^{2}$ yang mencapai 0,893 menunjukkan konsistensi model dengan hasil lapangan dan dengan demikian model dapat digunakan. Selanjutnya, model lalu lintas tersebut dimodifikasi dengan mengubah arah lalu lintas di sekeliling Landmark menjadi satu arah berlawanan arah jarum jam.

Perbandingan hasil kinerja lalu lintas pada kondisi eksisting dengan rencana SSA ditunjukkan pada Tabel 3 dan Tabel 4. Rata-rata kecepatan lalu lintas di ruas jalan adalah 15,6 km/jam dengan tingkat pelayanan (LOS) E. Kinerja lalu lintas pada simpang berkisar antara $\mathrm{D}$ dan $\mathrm{F}$, dengan tundaan rata-rata sebesar 60,3 detik/kendaraan. 


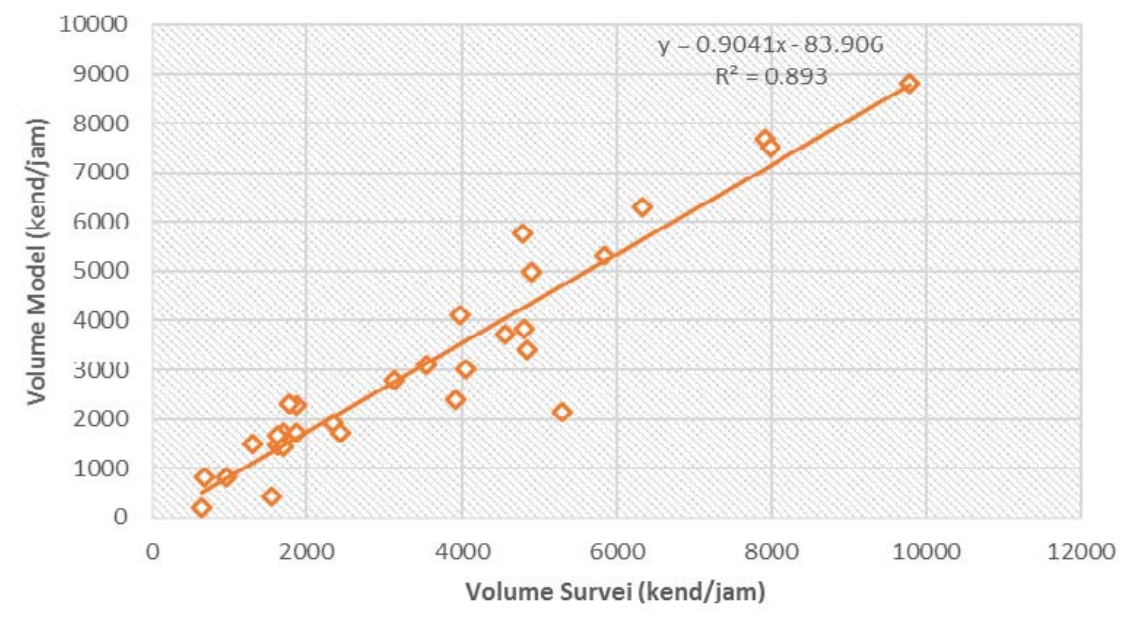

Gambar 4. Validasi Model Vissim

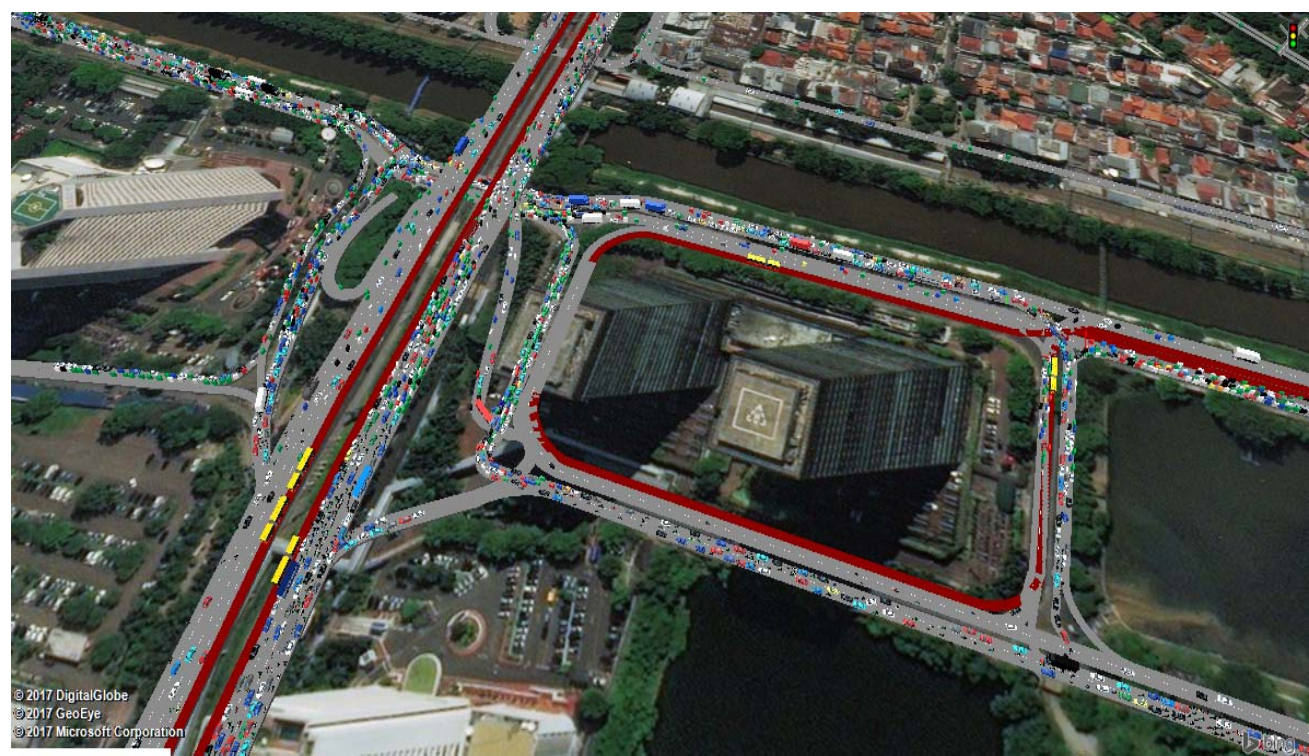

Gambar 5. Model Simulasi Lalu Lintas Eksisting Kawasan Dukuh Atas

Tabel 3. Perbandingan Kinerja Ruas Jalan Eksisting dengan Rencana SSA

\begin{tabular}{ccccccc}
\hline \multirow{2}{*}{ No } & \multirow{2}{*}{ Ruas } & $\begin{array}{c}\text { Volume } \\
\text { (kend/jam) }\end{array}$ & \multicolumn{2}{c}{ Kondisi Eksisting } & \multicolumn{2}{c}{ Rencana SSA } \\
\cline { 5 - 7 } & & & Kec & LOS & $\begin{array}{c}\text { Kec } \\
(\mathbf{k m} / \mathbf{j a m})\end{array}$ & LOS \\
\hline 1 & Sudirman - SU & 6767 & 22,7 & $\mathrm{E}$ & 22,7 & $\mathrm{E}$ \\
2 & Sudirman - US & 6330 & 7,1 & $\mathrm{~F}$ & 7,2 & $\mathrm{~F}$ \\
3 & Thamrin - SU & 4659 & 21,8 & $\mathrm{E}$ & 18,8 & $\mathrm{E}$ \\
4 & Thamrin - US & 8249 & 10,6 & $\mathrm{E}$ & 12,8 & $\mathrm{E}$ \\
5 & Margono - BT & 4756 & 20,8 & $\mathrm{E}$ & 43,2 & $\mathrm{E}$ \\
\hline
\end{tabular}




\begin{tabular}{|c|c|c|c|c|c|c|}
\hline \multirow[b]{2}{*}{ No } & \multirow[b]{2}{*}{ Ruas } & \multirow{2}{*}{$\begin{array}{c}\text { Volume } \\
\text { (kend/jam) }\end{array}$} & \multicolumn{2}{|c|}{ Kondisi Eksisting } & \multicolumn{2}{|c|}{ Rencana SSA } \\
\hline & & & $\begin{array}{c}\text { Kec } \\
(\mathrm{km} / \mathbf{j a m})\end{array}$ & LOS & $\begin{array}{c}\text { Kec } \\
\text { (km/jam) }\end{array}$ & LOS \\
\hline 6 & Margono - TB & 4517 & 15,1 & $\mathrm{E}$ & 16,5 & $\mathrm{E}$ \\
\hline 7 & Galunggung - BT & 4063 & 22,7 & $\mathrm{E}$ & 22,1 & $\mathrm{E}$ \\
\hline 8 & Galunggung - TB & 6396 & 10,3 & $\mathrm{E}$ & 7,4 & $\mathrm{~F}$ \\
\hline & Rata-rata & & 15,6 & $\mathrm{E}$ & 17,7 & $\mathrm{E}$ \\
\hline
\end{tabular}

Tabel 4. Perbandingan Kinerja Simpang Jalan Eksisting dengan Rencana SSA

\begin{tabular}{llcccc}
\hline \multirow{2}{*}{ No } & Simpang & \multicolumn{2}{c}{ Eksisting } & \multicolumn{2}{c}{ SSA Timur } \\
\cline { 3 - 6 } & $\begin{array}{c}\text { Tundaan } \\
\text { (detik/kend) }\end{array}$ & LOS & $\begin{array}{c}\text { Tundaan } \\
\text { (detik/kend) }\end{array}$ & LOS \\
\hline 1 & Dukuh Bawah & 35,7 & $\mathrm{D}$ & 15,56 & $\mathrm{~B}$ \\
2 & Galunggung & 89,4 & $\mathrm{~F}$ & 61,92 & $\mathrm{~F}$ \\
3 & Landmark Barat & 55,9 & $\mathrm{~F}$ & 53,6 & $\mathrm{~F}$ \\
\hline & Rata-rata & 60,3 & $\mathrm{~F}$ & 43,7 & $\mathrm{E}$ \\
\hline
\end{tabular}

Hasil pembebanan lalu lintas dengan rencana SSA, seperti terlihat pada menunjukkan terjadinya peningkatan signifikan di Jl. Margono arah ke timur dari $20,8 \mathrm{~km} / \mathrm{jam}$ menjadi 43,2 km/jam, sementara pada ruas jalan lainnya peningkatan yang terjadi kurang dari $2 \mathrm{~km} / \mathrm{jam}$ dan penurunan kecepatan terjadi di $\mathrm{Jl}$. Galunggung arah ke barat dan Jl. Thamrin arah ke utara.

Secara keseluruhan kinerja ruas jalan meningkat dengan rata-rata kecepatan lalu lintas menjadi 17,7 km/jam. Dampak penerapan SSA terhadap kinerja simpang adalah positif pada seluruh simpang. Tundaan pada ketiga simpang yang ditunjau menurun secara signifikan dengan tundaan rata-rata menjadi 43,7 detik/kendaraan. 


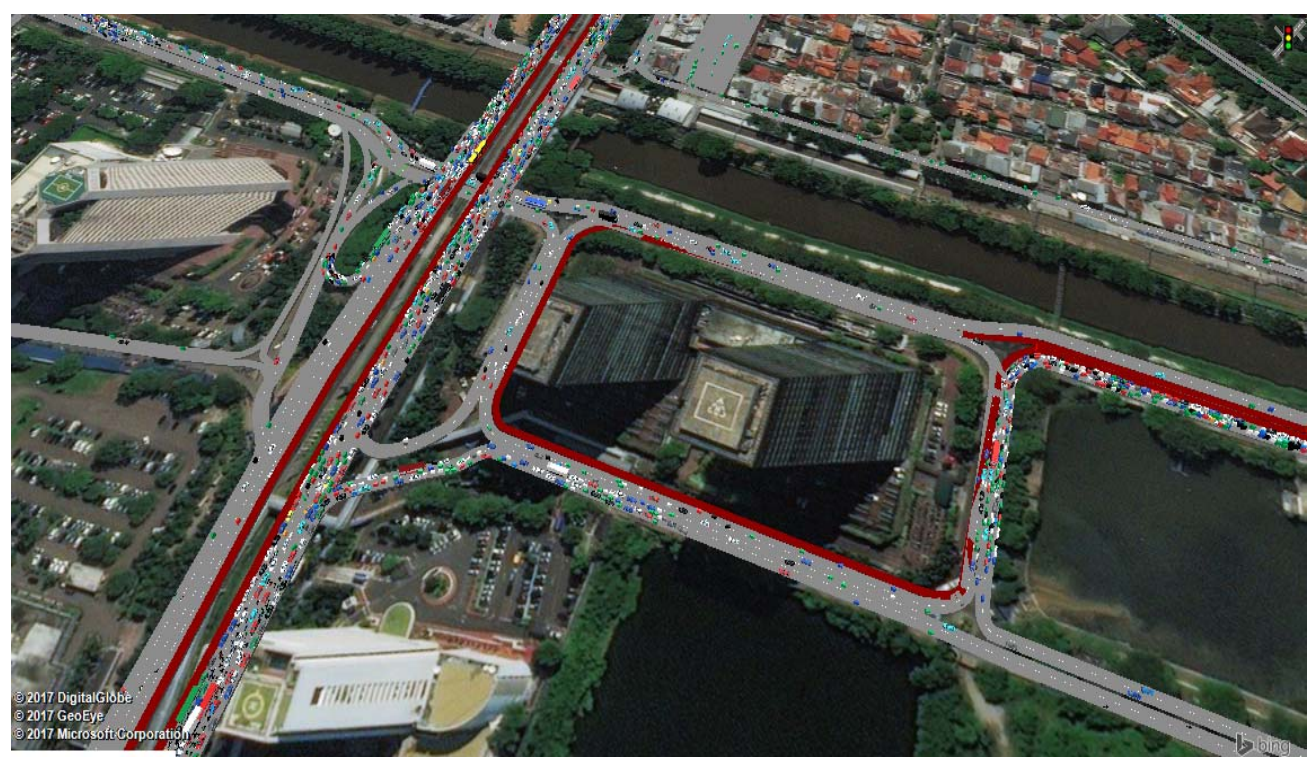

Gambar 6. Model Lalu Lintas Sistem Satu Arah di Kawasan Dukuh Atas

\section{KESIMPULAN DAN REKOMENDASI}

Kinerja lalu lintas kondisi eksisting di Kawasan Dukuh Atas memiliki kecepatan rata-rata pada ruas jalan sebesar 15,6 km/jam dan tundaan rata-rata pada simpang sebesar 60,3 detik/kendaraan. Dengan penerapan SSA, kecepatan rata-rata meningkat menjadi $17,7 \mathrm{~km} / \mathrm{jam}$ dan tundaan di simpang turun menjadi 43,7 detik/kendaraan.

Penerapan SSA diperkirakan akan meningkatkan kinerja lalu lintas di kawasan Dukuh Atas. Penerapan SSA ini akan lebih baik jika diterapkan juga pada kawasan Dukuh Atas bagian barat mengelilingi KCP BNI sehingga simpang Dukuh Bawah tidak perlu menggunakan APILL.

\section{DAFTAR PUSTAKA}

1. Departemen Permukiman dan Prasarana Wilayah. (2004). Survai Pencacahan Lalu Lintas dengan cara Manual. Jakarta: Departemen Permukiman dan Prasarana Wilayah.

2. Direktorat Pembinaan Jalan Kota. (1990). Panduan Survai dan Perhitungan Waktu Perjalanan Lalu Lintas. Jakarta: Direktorat Jenderal Bina Marga. 
3. Irawan, M. Z., \& Putri, N. H. (2015). Kalibrasi Vissim Untuk Mikrosimulasi Arus Lalu Lintas Tercampur Pada Simpang Bersinyal (Studi Kasus: Simpang Tugu, Yogyakarta). Jurnal Penelitian Transportasi Multimoda, 13(03), 97-106.

4. Negoro, Y. A., Munawar, A., \& Irawan, M. Z. (2018). Analisis Pengaruh Manajemen Kecepatan Terhadap Antrian Kendaraan Pada Exit Gerbang Tol Periode Liburan. Jurnal Penelitian Transportasi Darat, 20(1), 33-48. doi:10.25104/jptd.v20i1.649

5. PT MRT Jakarta. (2018). Laporan Final Usulan Panduan Rancang Kota Kawasan TOD Dukuh Atas. Jakarta: PT MRT Jakarta.

6. Putranto, L. S. (2010). The Evaluation of Space Mean Speeds of Road Links Surrounding New Developments in Jakarta. The Seventh Asia Pacific Conference on Transportation and the Environment Proceedings.

7. Syaukat, Y., Sarma, M., Falatehan, A. F., \& Bahtiar, R. (2015). Analysis of Willingness to Pay (WTP) to Determine Road Pricing in Jakarta. Scientific Journal of PPI-UKM, 2(6), 258-260.

8. Wikayanti, N., Azwansyah, H., \& Kadarini, S. N. (2018). Penggunaan Software Vissim Untuk Analisis Simpang Bersinyal (Studi Kasus Jalan Sultan Hamid II Jalan Gusti Situt Mahmud -Jalan 28 Oktober - Jalan Selat Panjang). Jurnal Mahasiswa Teknik Sipil Universitas Tanjungpura, 5(3), 1-11. Retrieved from http://jurnal.untan.ac.id/index.php/JMHMS/article/view/30477/75676579617.. 